\title{
Model for managing extracurricular activities of university students using information and communication technologies
}

\author{
Galina Klochkova* \\ Togliatti State University, Togliatti, 445020, Russia
}

\begin{abstract}
This article is devoted to use of information and communication technologies (hereinafter referred to as the ICT) in education, and their implementation in extracurricular activities of educational organizations. The relevance of the study is due to new trends in the education system in general and in extracurricular activities in particular. Theoretical studies are analyzed according to which a modern university graduate is required to possess general cultural and general professional competencies. It is shown that extracurricular activities at the university provide students with an opportunity to develop supra-professional competencies, create conditions for implementation of their creative potential. The essence of management in the educational system of extracurricular activities using the information and communication technologies was studied. The components of extracurricular activities are provided and the results obtained are described. The main attention in the article is paid to development and implementation of a model of management of extracurricular activities of university students using information and communication technologies. Hybrid extracurricular activities that are conducted with students using information and communication technologies are of interest. The material is of practical importance; it allows to use the offered model of management of extracurricular activities of students. This issue is multifaceted.
\end{abstract}

\section{Introduction}

Due to the global changes taking place in the social and professional sphere of the Russian Federation, a significant restructuring of the system of higher professional education is taking place. The most important task of modern state policy in the field of education is to improve its quality, as evidenced by the Federal Law "On Education in the Russian Federation". A modern university graduate is required to possess general cultural and general professional competencies, which imply mobility, the ability to adapt to changes in society, the ability to communicate with various social subjects, and much more. O. Povidaichik and S. Khominets define professional mobility as "an integral quality of a modern specialist ... and believe that development of professional mobility of specialists in higher education institutions is facilitated by development of a system for formation of professionally mobile personnel and

\footnotetext{
* Corresponding author: gal.klochkowa@yandex.ru
} 
creation of pedagogical conditions for its implementation" [9]. Professional training of a specialist (master, bachelor) is carried out in the unity of educational and extracurricular activities that is reflected in the Federal State Educational Standard of Higher Education.

Extracurricular activities at the university provide students with opportunities for development of supra-professional competencies, create conditions for implementation of creative potential in festivals, competitions, events, and provide information support.

According to the American researcher, B. Wegener, "... development of professional mobility of teachers, in the system of continuous professional education, can be carried out through: innovative teaching activities, ... management activities in the field of education" [10].

The unification of computer systems and global telecommunication networks made it possible to create and develop a planetary infrastructure that connects all of humanity. Modern telecommunication networks and their convergence with information technologies contributed to emergence of information and communication technologies (hereinafter referred to as the ICT) that became the basis for creation of the infosphere.

The modern world, according to N.V. Chernyavsky, has a wide range of information services [7]. "An example of the successful implementation of the ICT was emergence of the Internet - a global computer network with its almost unlimited possibilities for collecting and storing information, transmitting it individually to each user" [8, p. 32-37]. Currently, it is it that is a virtual platform and one of the main means of interaction between students in the process of educational and extracurricular activities.

"The study of the essence of management in the educational system of extracurricular activities is carried out in two directions. The "broad" direction lies in the fact that extracurricular activities are identified with educational work. The whole process of education, one way or another, is associated with upbringing. "Narrow" direction singles out the sphere associated with implementation of creative abilities, social activity and amateur performance of the student collective (extracurricular part of the educational process) from the educational process" [6].

We understand the extracurricular activities using the ICT as an arranged system of communication (online and offline) of students with each other and with the organizer of the process aimed at achieving a real result - a hybrid event.

To consider the concept of a "hybrid" event, let us consider the event industry. Based on materials from wikipedia, "the concept of "Event" has an emotional and entertaining basis, affects a person using various kinds of plot moves, visual techniques, lighting equipment, computer graphics, and etc. The concept of "event" includes an event, activity, ceremony and show" [5].

A hybrid activity is two formats - Online and Offline, combined into one event. This format is now gaining momentum and popularity, since in hybrid events it is possible not only to communicate through the screens of computers, but also to interact with some participants who will take part in Offline mode.

The area of our study is in direct relationship with the extracurricular environment. We understand the extra-curricular environment as a set of conditions (organizational, methodological, material, personnel, psychological) for meaningful leisure of students, contributing to the physical and spiritual development of their personalities.

Within the framework of our study, interpretation of the purpose of extracurricular activities made by Zh.B. Esmurzaeva "improvement and development of the communicative-activity component of the competitiveness of specialists" [2, pp. 113-115] was supplemented by two more components: cognitive and emotional-value ones.

Despite the urgency of the problem, the analysis of scientific studies and pedagogical practice testifies the insufficient theoretical and practical development of the foundations for use of the ICT for arrangement of extracurricular activities of university students, the 
readiness of students and educational institutions to use the ICT in extracurricular activities of various formats and absence of a model for managing extracurricular activities of university students using the ICT.

The purpose of this article is to study the level of the state of the components of management of extracurricular activities of university students (cognitive, behavioralactivity, emotional-value, communicative and resource ones) and to develop a model of management of extracurricular activities of university students using the ICT contributing to its qualitative change.

\section{Description}

We paid special attention to arrangement of the experimental work, its course and the results obtained.

To assess the level of the state of management of extracurricular activities of university students, the following indicators (management components) were determined:

1. Cognitive component. The cognitive component is associated with the level of knowledge (awareness) of students: about extracurricular activities, about the possibility of participating in events remotely; showing interest in the all-round development of one's personality.

2. Behavioral and activity component. The behavioral and activity component is provided through reflection of students' knowledge in educational, labor and productive activities, as well as the possibility to rely on this knowledge; the ability to communicate with adults and peers, the ability to choose, mutual assistance, the ability to find their place in a common case, the desire for cooperation, and achievement of the goal.

3. Emotional and value component. Emotional and value component - a manifestation of resourcefulness, responsibility, ability to quickly navigate in any situation, entrepreneurship; assessment of the manifestation of these qualities in peers; analysis of their own activities with a focus on a positive result.

4. Communicative component. According to researchers, the communicative component can be associated with implementation of advertising campaigns for extracurricular activities arranged by the university.

5. Resource component. Resource component is focused on providing the process with the necessary human and material and technical resources [1], without which it is difficult to carry out extracurricular activities in a modern university.

The study was carried out at the Togliatti State University. The respondents (151 students of 1-4 years) received a questionnaire represented by the following questions: How often do you visit the university website? How would you rate the material and technical equipment of the university for holding cultural events of various formats (offline, online, hybrid)? Do you take part in study events (conferences, round tables, scientific discussions, and etc.) arranged by the university? From what sources do you receive information on extracurricular activities carried out at TSU? Is there a sufficient number of cultural events held at the university throughout the year? How do you assess the arrangement of cultural events? What format of cultural events do you prefer? Are the conditions in the university conducive to the creative development of the individual? How willing are you to take part in extracurricular activities, and etc.?

The results of the questionnaire analysis showed that the university has created a good material and technical base for any type of activity (72.5\%). Information about events (cognitive component) at the university is arranged at a fairly good level: $72.5 \%$ receive information on social networks, $13.7 \%$ receive information by e-mail, $9.8 \%$ - on the university website, other sources were indicated by $3.9 \%$. 
Respondents (84.4\%) noted a sufficient number of extracurricular activities held at TSU, but $74.5 \%$ of respondents, as before, tended to hold them in the traditional format. The answers indicated the respondents' readiness to participate in events of various formats, to an active student life at the university outside of school hours.

Requirements for the information provided were determined: brevity, informational content, colorfulness and clarity, which was noted by the respondents as a shortcoming at the ascertaining stage.

The state of the "emotional and value" component of management of extracurricular activities of students was determined using the diagnostic methodology of M. Rokich "Value orientations" based on the direct ranking of the list of values.

For our study, the values of professional self-realization were more significant. In the system of values of professional self-realization, the highest rating (6th place) was taken by a productive life (the fullest use of one's capabilities, strengths and abilities). Then there was an active life (fullness and emotional richness of life); public recognition (respect for others, the team, workmates) and creativity (the possibility of creative activity).

The state of the communicative component of management of extracurricular activities of students was carried out by analyzing the TSU website. It was concluded that the site of Togliatti State University is detailed and well-designed, there are some points about the speed of loading and working with the site, but the amount of information provided fully complies with the educational standard. However, despite the detailed study and compliance with the educational standard, the TSU website is not popular enough among students to receive information about extracurricular activities. We plan to improve this indicator during the experiment, through the active use of the ICT in the management of extracurricular activities.

The analysis of the Development Program of Togliatti State University (hereinafter referred to as the TSU) made it possible to identify the state of the resource component of management of extracurricular activities of students (provision of the ICT infrastructure and personnel), as well as to analyze the readiness of the university for extracurricular activities using the ICT.

Commissioning a failover cluster of virtual machines, minimization of the probability of data loss in the event of failures in the information systems, operational scaling of server capacities in accordance with needs proved the security of TSU's IT infrastructure and its readiness for extracurricular activities using the ICT.

With the internal readiness of the university for extracurricular activities using the ICT and activity on the part of students, the data of the ascertaining experiment indicate an insufficient level of the ICT use in extracurricular activities, which is characterized by:

- low level of awareness of students and personnel about extracurricular activities using the ICT;

- low degree of development of opportunities for interaction using the ICT;

- low popularity of the TSU website among students in order to obtain information about extracurricular activities, including hybrid ones;

- the need to improve the qualifications of employees for use of the ICT in extracurricular activities.

We assumed that qualitative changes will occur in management of the extracurricular activities process, if:

- a diagnostic toolkit is developed and the state of the components of management of extracurricular activities of university students is identified;

- a model of management of extracurricular activities of university students using the information and communication technologies is developed and implemented.

Based on their analysis of the ascertaining experiment, the following work tasks were determined: 
1. To highlight the theoretical and methodological foundations for development of a model of management of extracurricular activities of students using the ICT.

2. To develop and gradually implement a model for managing extracurricular activities of university students using the ICT, including the promising and subject goals of the educational organization, the principles and functions of extracurricular activities.

3. To test the checklist of hybrid cultural, creative and event activities.

Systemic, personality-oriented, competence-based and activity-based approaches were chosen as the theoretical and methodological basis for development of the model of management of extracurricular activities of students using the ICT.

The systems approach allows to consider "ICT management" as a whole, consisting of parts that perform certain functions and are interconnected via a system of these functions. The personality-oriented approach is based on the ideas of Russian psychologists who consider the individual as a subject of activity. The competence-based approach allows to consider the content of the general cultural competencies of graduates.

The model for management of extracurricular activities using the ICT included: promising goals of the educational organization, subjective goals, principles, functions of extracurricular activities implemented in stages in the form of hybrid activities aimed at meeting the creative, intellectual and leisure needs of students.

The promising goal of extracurricular activities is to optimize extracurricular activities using the ICT implementation of which we carried out by solving the following tasks: arranging and holding events of a hybrid format, developing innovative activities, increasing the efficiency of interaction between organizers and participants on the one hand and participants in hybrid events with each other, on the other hand [3]. The subjective goal is to meet the needs of students for all-round development, to promote a positive image of the university and increase its competitiveness.

The organizational and regulatory component of the extracurricular activities management model is represented by principles, functions and conditions.

Due to introduction of the third generation of HVE by FSES in 2011-2012, I.V. Rudenko, in her study on the basis of TSU, identified "three fundamental principles of the content of educational work in the university: consistency, continuity, student-centeredness" [4]. This approach makes it possible to objectively include information and communication technologies in the management of extracurricular activities of the university, improving the management system, through implementation of a complex of complementary functions (informative, coordination and control and evaluation).

In order for extracurricular activities to be a link connecting development of professional and supra-professional competencies, it is necessary to observe two groups of conditions: social (creating an educational extracurricular environment; increasing motivation to participate in extracurricular activities; providing opportunities for self-realization and socialization of youth and organizational (creating a thematic information space on the Internet; development of content aimed at promoting hybrid extracurricular activities).

The model was implemented in 3 stages: preparatory, main, and final. The purpose of the preparatory stage is to develop a memo (provision) for a hybrid event; main stage - use of a hybrid format to traditional university events (Festival "Student Spring", "Day of Knowledge", "Evening of the Meeting of Graduates", "Student Initiation Ceremony", the festival "GREEN Show", "Open Day", "Tatiana's Day", "Victory Day" and the challenge competition DISCO 2020 Aerobics Show); the final one is the development of a checklist for a hybrid event. The assigned tasks were developed and implemented for each goal.

The effectiveness of the management model was assessed according to the following criteria: an increase in the audience of participants in extracurricular activities from among university students of all forms of study, representation and positioning of the university at 
the city, regional, national and international level, participation of active university youth at the city, regional, federal, international areas of volunteerism, culture and sports.

\section{Results}

As a result of the experimental study, qualitative changes occurred in the state of the components of management of extracurricular activities of students of all forms of education, which led to a change in value priorities, an increase in the degree of awareness and satisfaction with extracurricular activities of university students.

\section{Conclusions}

Implementation of the model of management of extracurricular activities of university students using information and communication technologies made it possible to: increase the virtual audience of extracurricular activities from among university students of all forms of education, increase the number of participants in hybrid events of different levels (urban, regional, international), position the university in the virtual space on a qualitatively new level. The conducted study does not pretend to be an exhaustive analysis of all aspects of the issue under study due to its versatility.

\section{References}

1. N. G. Bagautdinova, Vysshaya shkola segodnya i zavtra: puti preodoleniya krizisa (2003)

2. Zh. B. Yesmurzayeva, Teoreticheskiye Podkhody, Zakonomernosti, Printsipy Issledovaniya Vneuchebnoy Deyatel'nosti Studentov, 3 (2014). Access mode: http://cyberleninka.ru/article/n/teoreticheskie-podhody-zakonomernosti-printsipyissledovaniya-vneuchebnoy-deyatelnosti-studentov

3. Kontseptsiya vneuchebnoy deyatel'nosti studentov Tol'yattinskogo gosudarstvennogo universiteta resheniye № 674 ot 20 dekabrya 2007 goda, 5-11 (2007)

4. I. V. Rudenko, Vospitaniye v professional'nom kontekst, Vektor nauki Tol'yattinskogo gosudarstvennogo universiteta, 1, 259-262 (2012)

5. Servis voprosov i otvetov Yandeks.K'yu Event kompaniya chto eto: Chto takoye event agentstvo? Access mode: https://ruorbitalwars.ru/raznoe-2/event-kompaniya-chto-etochto-takoe-event-agentstvo-yandeks-kyu.html

6. Yu. V. Khrul'kova, Osobennosti upravleniya vneuchebnoy deyatel'nost'yu vuza, Nauchno-tekhnicheskiye vedomosti SPbGPU, 3, 383-386 (2009)

7. N. V. Chernyavskiy, Pochemu lyudi predpochitayut virtual'nuyu real'nost' deystvitel'noy, Mezhdunarodnyy zhurnal prikladnykh i fundamental'nykh issledovaniy, 11 (4), 823-826 (2016). Access mode: https://appliedresearch.ru/ru/article/view?id=10706/

8. A. I. Yakovlev, Informatsionno-kommunikatsionnyye tekhnologii $\mathrm{v}$ obrazovanii Informatsionnoye obshchestvo, 32-37 (2001). Access mode: http://emag.iis.ru/arc/infosoc/emag.nsf/BPA/bce6d4452de1cad0c3256c4d0052530

9. O. Povidaychyk, S. Khominets, Pedagogical aspects of professional mobility of a modern specialist, The scientific heritage, 37, 52-55 (2019)

10. B. Wegener, Job mobility and social ties: social resources, prior job, and status attainment, American social review, 1, 60-71 (1991) 